\title{
Por Las Espaldas Se Nos Van Entrando Con Silencio: Fr. Hidalgo's Letter to the Viceroy
}

Mariah F. Wade

Unknown

Follow this and additional works at: https://scholarworks.sfasu.edu/ita

Part of the American Material Culture Commons, Archaeological Anthropology Commons, Environmental Studies Commons, Other American Studies Commons, Other Arts and Humanities Commons, Other History of Art, Architecture, and Archaeology Commons, and the United States History Commons

Tell us how this article helped you.

This Article is brought to you for free and open access by the Center for Regional Heritage Research at SFA ScholarWorks. It has been accepted for inclusion in Index of Texas Archaeology: Open Access Gray Literature from the Lone Star State by an authorized editor of SFA ScholarWorks. For more information, please contact cdsscholarworks@sfasu.edu. 


\section{Por Las Espaldas Se Nos Van Entrando Con Silencio: Fr. Hidalgo's Letter to the Viceroy}

\section{Creative Commons License}

\section{(c) (1) ()}

This work is licensed under a Creative Commons Attribution-NonCommercial 4.0 International License 


\title{
POR LAS ESPALDAS SE NOS VAN ENTRANDO CON SILENCIO' ${ }^{\text {: }}$ FR. HIDALGO'S LETTER TO THE VICEROY
}

\author{
Mariah F. Wade
}

\begin{abstract}
The translation of historical documents is essential to the practices of archaeology and ethnohistory. The present translation presents the complete text of a letter written by Fray Francisco Hidalgo to the Viceroy of New Spain on November 4,1716 . This translation strives for accuracy and adds contextual information to enhance the value of the document. Fray Hidalgo's letter exemplifies how Spanish officials acquired information about the French and the various Native groups, and how they viewed their interrelationships, actions, and customs. It confirms that Fr. Hidalgo did write two letters to the French officials in Louisiana, includes important floral and faunal information, provides locations for the Apache and Pawnee, and states that Diego Ramon traveled to the Mississippi River and visited Mobile. The epistle provides information on the geo-political and economic paradigms of the time, and how they shaped Spanish policy.
\end{abstract}

\section{Introduction}

The early history of the relationships between Spanish friars and Native American groups, in what is today northern Mexico and Texas, does not portray a vehement repugnance on the part of the Native Americans to accept the Catholic faith. The Caddo groups of East Texas were the exception. Starting in 1691 and at various times afterwards, Franciscan friars supported by the military actively tried to Christianize Caddoan-speaking groups. They were ignored, rebuffed, and twice expulsed. Although the Caddo asked and actually invited the Spanish and their friars into their lands, they quite emphatically refused their religion. The Caddo accepted the Spanish presence, welcomed their trade, and played them against the French, but most abstained from Catholic religious practices. It is possible that researchers have not completely understood the essence of this refusal nor the strength of Caddo religious practices and convictions.

Fr. Francisco Hidalgo was undoubtedly the principal force behind the return of the Spanish to Caddo country in $1716^{2}$. To return to the Tejas country, he exploited and profited from the continuous strong-arm contest between the Crowns of Spain and France. Fr. Hidalgo was an experienced and crafty politician who, by his own admission, had made an agreement with Bernardino in 1691, when the Spanish first tried to settle Caddo country. Bernardino was one of the principal leaders of the Tejas. According to this agreement, Fr. Hidalgo had promised to return to East Texas whenever circumstances allowed it. Fr. Hidalgo clearly believed the Tejas ${ }^{3}$ wanted the presence of the Spanish and were willing to undergo the process of Christianization. The peremptory order given by Tejas leaders to the Spanish to abandon their territory proves that he was mistaken.

What follows is the translation of a letter Fr. Francisco Hidalgo (1716) wrote to the Viceroy ${ }^{4}$ in November 1716. The letter was written at the Spanish Mission of San Francisco de los Tejas which had just been re-established by Fr. Hidalgo near the Neches River. This letter was translated by Mattie Austin Hatcher and published in the Southwestern Historical Quarterly (Hatcher 1927:53-62). Hatcher's translation has some omissions and, at times, she appears to have misconstrued some of the meanings. In 1942, 
Swanton (1924:256-271) published the full Spanish text. Both Swanton (1942) and Griffith (1954) used Hatcher's translation even though Griffith considered Hatcher's translation "not entirely trustworthy" (Griffith 1954:note 6). The present translation includes the full text as it appears in a typescript at the Texas History Center (Hidalgo 1716), and attempts to clarify some of the points obscured in Hatcher's translation.

Fr. Hidalgo's letter is an important document for a variety of reasons. First, it testifies to the unorthodox methods Fr. Hidalgo used to force the hand of the Spanish Crown into returning to Caddo country and confirms that he wrote two letters to the French officials in Louisiana. Second, it clearly demonstrates Spanish efforts to Christianize the East Texas groups and Fr. Hidalgo's realization that these groups were far from willing participants in the enterprise. Third, it provides clear testimony of the political fencing and boundary maneuvering between the French and the Spanish. Fourth, it provides important cultural information about the Caddo groups and about their customary buffalo hunting grounds. Fifth, it locates the Apache west of the Pawnee and northwestward of the Caddo. Significantly it declares the Apache as enemies of the Pawnee but fails to identify the longterm traditional enemies of the Caddo. The omission of the Apache as the traditional enemies of the Caddo is noteworthy particularly because Fr. Hidalgo had been in the Caddo country in 1691, and was probably better acquainted with the Tejas groups than any other friar at that time. Since Fr. Casanas, who had been in East Texas in 1689 and was also well acquainted with the Tejas (Canedo 1968:53), specifically mentions the Apache as enemies of the Caddo, either some major realignment had taken place between 1691 and 1716 , or we appear to have been given incomplete or contradictory information.

Four other points make this document historically important. First, Fr. Hidalgo gathers information, evaluates the geo-political and economical data about the region of East Texas, Missouri, Mississippi, and even Florida, and passes it on as a modern intelligence official would. Second, the letter documents both the geographical knowledge and misconceptions of the Spaniards at the time. Third, the letter abundantly shows that the majority of the information obtained by the Spaniards was obtained from Native Americans, and, fourth, it makes it clear that Diego Ramon traveled the Mississippi River and visited the French settlement at Mobile. It would be disingenuous to believe that these forays into French territory had no connections with later trade arrangements between the Ramon family and French traders, particularly Saint-Denis.

The translation that follows is a liberal translation inasmuch as word choice, some punctuation, and, in a few cases, sentence order have been altered to clarify meaning. Most of the original punctuation, as it appears in the typescript, is included in the text. Because of sentence construction, however, most commas had to be removed. All words and punctuation that have been added appear between brackets. For example, where a period has been added the original punctuation will appear followed by the added period between brackets and the capitalized word. Alternative words which could have been chosen, or whose compound meaning appears to reflect more accurately the meaning conveyed by $\mathrm{Fr}$. Hidalgo, also appear between brackets. Original Spanish words used in the text appear in italics and between brackets. Words underlined or words between parenthesis appear in the original text. All capitalization and spelling of Native or Spanish words are transcribed as they appear in the original text. To make the letter more comprehensive the author chose to spell out most abbreviations. An asterisk indicates where sentence order has been significantly altered in order to clarify meaning. Notes that appear throughout Fr. Hidalgo's letter are obviously not part of the original text and refer to the commentary notes added by the present author. The reader is advised that no translation conveys completely the meaning of the original, particularly translations of historical documents for which linguistic and complete historical contexts are not well known. This translation is no exception. 


\section{Letter from Fr. Francisco Hidalgo to Viceroy:}

"I feel this is the right time to write this letter to Your Excellency, first because His Excellency the Viceroy, your predecessor ${ }^{5}$ called me to that court to propose to me the entrada to the tejas, [and] the writing of a report on the land, and its divisions ${ }^{6}$ [distritos], [second because] the Indians of this nation requested me as their minister; since I knew them earlier on when I lived in the area, ${ }^{7}$ and [because] these Indians have persisted in this request since the time when this land lost its settled population ${ }^{8}[$. 1 Since I left [this land] I kept the pact [made] with their Principal Captain ${ }^{9}$, now deceased, to return with ministers; [. ] Finding myself with this obligation: I persisted and have done all that it was possible to achieve this objective [by pleading my case] to my brothers, and superiors, to His Catholic Majesty, and to his Excellency the Viceroy Duque de Albuquerque [, 1 Due to certain incidents all the efforts were fruitless and nothing was accomplished. Realizing that all the methods used had failed; [,] I thought of a good stratagem [device, solution]. I knew that this land and the lands to the interior were being settled by the french, [and since these lands are known] to be close to the lands of His Majesty near the Seno Mexicano; and [since the French] which with great impetus have been getting closer to those borders of New Spain: I decided to write them two letters on different occasions (to see if I could receive a letter from them, which I could forward to your Government) and one of those [letters] reached their hands, [. ] The answer [to that letter] was the arrival of two frenchmen at that court, and with the information [obtained from the two Frenchmen] and other [information] that Your Excelleney elicited from different people; [that Government] determined that this conversion should proceed with a small force of twenty-five people, [and] ordered that four missions be established, sending [to these missions] religious brothers from the College of SS. Cruz de Queretaro, without providing for their maintenance, as well as ordering me to supply His Excellency with information about the land and all other things [. ] These are the motives that make me pick up the pen, and provide you with a report [relacion] regarding all this land [,] the Indian form of government, their false Religion, the divisions this nation has, the fruits the land provides and the ways that we can adopt, in order to make this land a Kingdom settled with a large population, [and] with many good prospects 
both spiritual and temporal. On January 21 [1716] five priests left the College of SS. Cruz de Queretaro joined the military company at Saltillo, and continued on our journey [and] on June 28 of this present year of 1716 we reached the borders of the province of the tejas [. ] After these Indians gave to our spaniards a proper reception and necessary courtesies and [after] the establishment of the four missions we informed the Government [of these things]: at present it remains to inform you of our experiences and the information we have acquired during our stay in this land, which [knowledge] is so necessary: [. ] Your Excellency will be good enough to consider them: in order that from the totality [of the information] we can get good results. [T]his Assinay Nation which we call tejas, or texias, has many divisions (parcialidades), ${ }^{10}$ [and] it extends to the Missuri River, [which] according to news from the Indians [the nation or the parcialidades] extend from north and east with large and small settlements, l. 1 On the north side, looking from that court [Mexico City] in this direction, are [located] the four missions for different parcialidades, [and when] facing this first mission of S. Francisco de los texas, the first two all to eastnortheast, another to the east, and another [still] to the northeast all [placed] at convenient distances. Following the northern mountain chain ${ }^{11}$ at $[\mathrm{a}$ distance] of about 53 leagues [138 miles] are the parcialiadades of the Cadodachos, Nazoni, Nacitos, Nadzoos: further inland near the Missuri River, is the great settlement of the caynio, tobacana and others [. ] Towards the east, [there is] the settlement of the Nachitoz, which the frenchmen are settling, and [there are] other [settlements] which border on the Settlement of the french which are [located] at the mouth of the missuri River, [where] it enters ${ }^{12}$ the River of la Palizada ${ }^{13}$. This first mission of my Father S. Francisco is at 33 degrees of height of the pole aligned with the north, and [if one] faces queretaro it is in 21 degrees on a straight south line ${ }^{14}$. This people are very pleasant, happy, with good features, [. ] Their faces are long and with hollow cheeks ${ }^{15}$ which make their noses more prominent [,] and [they are] friendly toward the spaniards. They sow Corn, beans, sunflowers which are so big as to be misshapen, their seeds are of the same size as [those] of the Corn which they eat in different soups for stews [ which they make with Corn and beans, [and] there are Pumpkins, melons, [and] Watermelons; they gather large quantities of acorns [and] 
Nuts in their shells, [which they store] for their yearly supplies. All this land has many different Trees, Oaks, chestnuts, pines, Cottonwoods, Loquats, plum trees and many others which I do not know. [The land] has vines of wild grapes, Passion fruit, Mulberries, white and black blackberries of two Types, and in some parts flax, [and] hemp [as is the case near] this first mission: and in some of the areas on the way [here] there are [also] great quantities [of flax and hempl, [. The land] has many springs, large and small Rivers, [and as] for the areas we have surveyed all the land is very wooded and has many small clearings, empty places and marshes where the settlements of the Indians are located, I. I We have not found in this area [any] good places to gather the Indians in a settlement; unless we cut and clear the woods. [T]he land has lagoons with different types of fish [and these] fish are also present in the Rivers [. I There are Many prairic chickens [true prairie chickens or turkeys?], Deer and during the cold weather Many gcese and ducks. They obtain buffalo to the west [and also] about two days travel towards the northeast: they have their enemies in sight, and this assinay nation has every year wars with the said enemies over the eating of meat, and [as a result] of ancient enmities that exist between both groups [. These wars] take place in very extensive prairies. As far as we have determined all this Nation is Idolater, they have houses of Adoration and [they have] the perpetual fire, which they do not let be extinguished, [. ] They are very superstitious, *and they will believe the visions related to them by the Indian male or female who gets drunk on the peyote, or the small bean, [mescal bean?] during the Dances that they hold, 1. I They prepare [this drink] specifically [for the celebrations]; they have large and small Idols, they recognize the Devil, and offer sacrifices to him as if [entendiendolo] he was their true God, and in the paintings which they make they portray him with horns [Cornudo] with a face of fire and in other ways, which clearly tells of their considerable error. We have not been able to [convince them] to place their houses near the church, although in the beginning they agreed [to do so]. And so there is no christian doctrine [being taught], first because of the great distaste they have toward all things christian, [second] because of the great distances between the houses, and [third] because of other reasons they hold. |T|he repugnance toward Baptism [,] which is well known [, exists] because the other time they reasoned that the water killed them: [when] some young [people] and adults 
were baptized and died. They will not consent if someone takes fire out of their houses, because they believe that [if that occurs] someone from that dwelling will perish. The houses are [made] of zacate [some are] very big and tall and others of medium size, and others [still] smaller in the shape of a half-Orange, and in these houses dwell many families,[. ] They keep the Corn in raised platforms and lofts, and in large baskets [made of] bamboo [reed, cane]. [They] place [in them] the shucked corn, and in othcr [baskets they place] beans, acorns, and Nuts. [T]hey make very large Ollas ${ }^{16}$ to prepare the atoles ${ }^{17}$, to store the water and for all their transportation [needs and] they have other vessels for their service. [T] hey make very curious mats of bamboo [reed, cane] and of different colors; which can be used to place on the floor of ladies' drawings rooms ${ }^{18}$; [they make] very interesting small bags of the same [material], and from the bamboo [reed, cane, they make] other small things which are used as Sieves [and] to clean and to serve the food they eat. [T]his land suffers from many plagues during the summer and because of the [many] Dogs [that exist] and which steal, as well as [because of the $]$ large horse-flies $[\text { Nozcones }]^{19}$ it is difficult to raise cattle except for goats and sheep [. I Last time all the animals of this type died [and] at this time raising any [cattle] is only accomplished with great labor. It is not possible to raise a large number of horses and mules because of the wooded and hilly nature of the land. [W] hat can be raised are bulls, cows, kids, and pigs and some horses. These Indians sow their lands communally with wooden hoes, and have great appreciation for iron hoes; they build their houses communally and they have axes [hachas] of different sizes which they acquire from the french. They sow tobacco [. I All the female Indians work harder than the men. [T] he men spend their time surveying [patrolling the country], and taking care of their Wars: ordinarily the wars of these Indians take place in winter. They acknowledge [accept] the authority of higher placed Indians [superior] regarding the fulfillment of these two endeavors [war and reconnoitering or patrolling]: in all else they are the masters of their own Will. [T]he scalps of their enemies are hung from cane poles at the entrance of the doors of their houses as trophies [and signs] of victory. [T] hey bathe their dead before they bury them with the trophies they have obtained [during their lifetime and], with the gamuças [deer skin clothing] they possess, and all their kinfolk make offerings and 
they place [in the graves some] of all their foods, as well as buffalo skins. $[T]$ he scalps [are included in the burial offerings] in order that their enemies will render them service in the afterlife, and the food is for the journey [into the afterlife], and the gamuzas and other things [trastes] to have clothing to wear [in the afterlife]. They do like clothing: but the things that Your Majesty has given them do not benefit them because [as soon as they obtain those presents] they share them with their friends. [The people of] this nation are always in contact since they visit each other continuously, [. ] There are many non-Christians and it increases throughout the divisions which I have mentioned above [and their number increases as you go further inland?: With the small [military] force we have we cannot try to gather them in pueblos, and the terrain does not help at all in that endeavor because of its wooded and hilly nature and [also] because of other conditions surrounding the area: [. ] It is necessary to keep in mind this point, and in my modest opinion to achieve long-term success, I would suggest [propose the following]: we need to survey the prairie lands, which lay to the northwest about two days travel from this mission where, I think, runs the River of SS Trinidad, according to the news of these Indians ${ }^{20}$. [I] think that those [are the] closest lands [to this area which arel appropriate to raisc horses and mules as well as Cattle and goats and sheep; with time, we will be able to move this people [move the Tejas out of their lands and into the Trinity River area?] by persuading them [with gifts| and [by] being friendly to this people |. I The military force will serve to dissuade them [from objectingl. |F linally time will help to solve any problems; and the experience obtained [in the process of colonizing this people] will indicate the best method to adopt. [O]utside of this settlement it is necessary that Your Excellency foster the scttlement of espiritu Santo bay,[. I According to my own survey betwcen the San Marcos and the espiritu Santo Rivers, before they join to enter Espiritu Santo bay, there are large and spacious prairies and very convenient places to establish large spanish settlements, [. I The climate [there] is more temperate than the climate at this place, because Iherel there arc heavy snowfalls in the winter, as I personally experienced before, [. ] Regarding the place [of the settlement of the French ${ }^{21}$ I have learned [that it must not be a good place to settlel because of the many frenchmen that died, the many plagues which are said to occur 
there lin the area of the bayl; and the fact that it is surrounded by Nations of enemy Indians both in the Islands of the Bay [of Espiritu Santo] and also in their environs which together constitute a whole body [lands or Native groups? $]^{22}$. $[\mathrm{H}]$ aving surveyed the $\mathrm{S}$. Marcos River above the junction with the espiritu Santo River; I found a spacious lagoon, which we think, constitutes the point where the S. Marcos River empties itself, and [the waters of the lagoon] with little wind make waves just like the sea ${ }^{23}$. [T] he tejas call it Sapinay [which means] the pregnant one ${ }^{24}$. [P]roceeding further toward the junction [of the two rivers] we found the small red hill, which was recognized previously, when [one] viewed it from the bay, as being at the margins of the Colorado River, or espiritu Santo River. [T] wooded belts in some areas, and on the margins of the Rivers [there are many kinds] of timber [good] for building. [I]n these prairies which border on the pregnant lagoon we can establish the settlement, and I think that a boat can sail upstream and end up at the lagoon to survey the advantages that [the lagoon and those lands] offer, [. ] At this place we could establish the first spanish settlement [which would serve to link] the commerce of all this land and specifically the [commerce] inland from the Texas. [T]his settlement would be located in a good place to link the borderlands of the Rio del Norte where the Presidio and Missions are located and this land of the Texas, [. ] Using the harbor at the bay [Espiritu Santo] we can settle this land with more impetus and less delays and His Majesty will save on the land freights. [Furthermore] we will safeguard the harbor, and by proceeding to subjugate the Indians in areas around the bay, solve the difficulties in the crossings and pacify the land. [I] have stated above that only if we clear the woods, can we place the missions in the manner I mentioned, and [it is] worth considering this point since if we abandon this land to settle the prairies the french (on behalf of france) will settle it, as the two frenchmen who visited that court proposed to your predecessor. These matters of jurisdiction and advantages for the settlers, and the military, as well as the subjugation of these Indians require a great deal of consensus, since [these Natives] with little effort will follow the french [because] of they way they accept [the ways of the french]. IT/he method [the French use] to settle and establish missions is very different from the spanish method. We will not be able to prevent problems and controversies / with 
the French] unless we take from them the place of Nachitoz. Captain Domingo Ramon will inform you about these matters [as well as about] the entrada he made to Nachitoz and [how] he ordered the two frenchmen who remain there as rearguard to erect a cross and an altar, and [how] the Saint Sacrifice of the mass was celebrated, and [how] he entered [carrying] the Royal Standard. [B]ecause he was sick, [it was] his brother Diego Ramon who, by canoe, proceeded downstream to survey the settlements of la Palizada and from there to survey la mobila. I shall continue to provide Your Excellency with some news which I gathered from the frenchmen, but to make the matter clearer I will provide Your Excellency with the direction that the Course of the Rivers [follow]. The River of la Palizada flows North to south, and the two Rivers - the one of the caddodachos ${ }^{25}$ which is the same where further downstream the Nachitoz and the two frenchmen are located: and the great Missuri River, [both] flow from west to east, and they empty themselves on the said River of la Palizada [. ] These rivers empty [into La Palizada] on this side [west] of the side we wish to settle, and [we wish] that france will not penetrate further into our borders of New Mexico, parral and south Sea, which [is] where the province of Sonora [is located]. $[\mathrm{H}]$ aving said this I shall convey the news which I have gathered about the Missuri River: [. ]At the place where this River empties itself are located two missions of the french Fathers of the Company [Jesuits], settled with the Yllinois Indians [together with] a french settlement; [. ]They have sounded the greater portion of the River upstream, [and they] trade with the Caynigua and Panni Indians, [the latter being] white Indians: [. ] They trade Clothing, french weapons, beads, and other things: they consider [these Indians [ as theirs, [and] they have not settled [among them] but they intend to settle all of this River: [. ] They have informed me that from the Yllinois upstream to the Panni [villages] there are 150 leagues: [390 miles distance. I At the location of these Panni settlements three branches of River join ${ }^{26}$, [and these branches] form the Missuri River, which they say runs as full and [is] as large as the River of la Palizada. These Indians are neighbors of the Apaches ${ }^{27}$, and have Great Wars with them, and it has been acknowledged that the Panni are Better Warriors than the Apaches: [. The Panni] have captured many |Apache] prisoners, who they sell to the french and the latter buy them and keep them as slaves. These three River branches 
issue from a large mountain range ${ }^{28}$ which borders with the South Sea [and has] many springs. They say that inland from the middle branch there is a large city, which years ago was discovered by a french clergyman and other secular [priests] and that they informed the French King [of this discovery, [. ] After that event [the french] have made several entradas upstream on that River, and I learned that [the people of] two or three [of those entradas] have been lost [.] Some years ago I learned that one hundred and fifty frenchmen penetrated [that country], and I do not Know what happen to them. This great city is not inhabited by Indians, but by white people, and they must be the tartars, or the Japonese: [. ] The most recent french Report [Relacion] says that from the other side of the mountain range and [from] its summit, one can see the coast and [the] south sea and many ships. Fr. Juan Torquemada talks about this white people in his Monarchia Indiana, ${ }^{29}$ [. ] If [one considers] the efforts both by land and sea that in times past were ordered to be made by His Excellency the Viceroy in Mexico [to make such discoveries one can realize how ] with all the present news we have faired in comparison with the frenchmen: quietly they have entered through our back door: [por las espaldas se nos van entrando con silencio. ] But God sees one's intentions. [Thus] Your Excellency all this requires redressing, and should it be possible to repair this great harm [danger] which has penetrated our doors, even at the cost of abandoning some of the Presidios of La Vizcaya, the richness with which god has endowed this land will provide the impetus, in order that, in time, [this enterprise] will be self-sustaining: [. ] Some of the people who participated in the present entrada, and who are knowledgeable about minerals, found that these are Lands of Minerals and have not found any other stones, only minerals, [. ]The waters all issue [from] mineral [sources]: [. ] We have not been able to do any experiments because we have been impaired by the sick and [byl other accidents that have occurred, [therefore] this subject has been postponed. To establish the Pueblos, and to Gather the Indians the best way to form a settlement [is to include] christian Indians who know the castilian language such as those [Indians] from new spain. [F] or the exploration of the mines [we need] spaniards who are knowledgeable about minerals. [A]nd to profit from the hemp, and linen His Majesty should be informed and asked [to provide?] the people from spain who would be more suitable [for that exploitation], 
[.] The same applies to the vines: if Your Excellency and the Government agree [with this proposal]. The same should be said for the silk, because there is an abundance of mulberry bushes and trees in this land [.] These Thejas Indians do not provide us with anything, they simply visit us. [T]he needs we experience for our sustenance both in services and food supplies [, I we remand them to god who has ordered that it be so, [. We do all this] for the greater honor and glory of God, for whose sovereign Majesty we have endured all [these sufferings]. I apologize for not including some of the details of the entrada to Nachitoz, the settlement and divisions of the land [seen] on the way; as well as other news acquired with the entrada of your Lieutenant to la palizada and mobila: [he will provide that report since] it is his job to do so. [1] figure [however] that Lieutenant Diego Ramon will not survey the mouth of the Missuri River where there is a settlement of the french and Yllinois Indians [.] As I have reported above to Your Excellency it is also necessary to reconnoiter that area and establish a border for [the Frcnch] in order that they will not proceed further upstream to discover the great settlements, which they intend to control [. ] All their communication takes place using the River courses and if we place a border near the Yllinois, [another] at Nachitoz and [another] at espiritu Santo bay: the french will be surrounded, [. The French, in turn] have the English of new Carolina also surrounded. [A]lthough the settlement of Panzacola has the french at its door, it is very necessary to preserve that harbor and to fortify it further with a good castle and a surrounding wall even if a good deal of the Royal treasure is spent [on the work]; [this is ] especially true at this time when there is War with france [and] it would not take much for them to take it [Pensacola]: [. ] This much I have heard them say, and in past wars spain would have lost the harbor and the English would have gotten it if the french of la mobila had not helped from behind [or helped with finances?]: [. 1 The Harbor of Penzacola is the best harbor His Catholic Majesty has in all the Indies for sheltering many fleets as I heard it said by the cosmographer of His Majesty in times past when they went to reconnoiter the sea. [W Iith all these precautions his Majesty would make sure [that] a Great Kingdom [was built], in these vast and rich provinces. God preserve the life of Your Excellency for many years for the promotion of the Holy faith and further development of the Royal crown. Mission de S. Francisco de los tejas today, 4 of November 1716 Signed Fr. Francisco Hidalgo. 


\section{NOTES}

1. The title of this article is a sentence used by Fr. Hidalgo (1716) in this letter to describe the advance of the French into what the Spaniards considered their territory. Por las espaldas se nos van entrando con silencio can be translated as: silently, or quietly, they have entered our back doors.

2. Fr. Francisco Hidalgo was a member of the expedition to the Tejas which took place in 1691. This expedition was led by General Domingo Terán de los Ríos and Fr. Damian Massanet.

3. Because of the problems relating to the various divisions of the southern Caddoanspeaking peoples in East Texas, the author prefers to use the designation used by the Spanish at the time the document was written. For a discussion of the information about the various divisions or parcialidades of the southern Caddo, see Griffith (1954), Perttula (1992), and Swanton (1942).

4. Viceroy Fernando de Alencastre Noroña y Silva, Duque de Linares, Marqués de Valdefuentes held his post from January 15, 1711, through August 16, 1716 (Polzer 1977:100). He succeeded Francisco Fernández de la Cueva, Duque de Albuquerque, Marqués de Cuellar who held the post from December 28, 1702, through January 15, 1711 (Polzer 1977:100). The Duque de Linares was in turn succeeded by Baltazar de Zúñiga, Guzmán Sotomayor y Mendoza, Marqués de Valero, Duque de Arión, who governed from August 16, 1716, through October 15, 1722 (Polzer 1977:100). It appears that $\mathrm{Fr}$. Hidalgo was referring to the Duque de Linares because he mentions his requests to the Duque de Albuquerque, but he could be referring to the Marqués de Valero since the Duque de Linares had left office by the time Hidalgo's letter was written.

5. See previous note.

6. The Dictionary of the Real Academia Española (hereafter referred as RAE) defines distrito as: "La extensión, espácio ù termino de alguna Província, y generalmente qualquier espácio de tierra" (RAE 1732:314). Thus, although a district could denote a particularly demarcated extension of land it could also denote, in a general sense, any given portion of land.

7. As stated in note 1, Fr. Francisco Hidalgo remained among the Tejas from 1691 through 1693 at which time the Tejas forced the Spaniards to leave (Canedo 1968:312319).

${ }^{8}$. Fr. Hidalgo, like most Spanish reporters, considers that an area was settled only when it was settled with Europeans. Native populations, even when inhabiting areas with fixed dwellings, are generally acknowledged as living in settlements but not as truly settled. This bias often leads to misunderstandings about unpopulated versus populated areas (Wade 1998:74).

9. It appears that the Native Captain or caddi referred to by Fr. Hidalgo was Bernardino, who was said to be the nephew of the Tejas Governor, and who had visited the Viceroy in Mexico City (Canedo 1968:34, 184, 264, 318). If this is correct, Bernardino was deceased by 1716 . 
10. The RAE defines parcialidad as: "Se toma tambien por el conjunto de muchos que componen una familia ò facción, lo que es común entre los Indios... Porque en conquistando cada Provincia luego reducian los Indios à Pueblos y comunidád, y contabanlos por parcialidades, y à cada diez Indios ponion uno que tuviesse cuenta de ellos" (RAE 1739:125). Thus, the notion of parcialidad had a particular meaning in colonial settings. It denoted a large group of Natives that could constitutc a family or a faction. The dictionary specifies that when the Spaniards conquered a Province they placed (reduced) the Natives in pueblos and counted them according to their factions or families (parcialidades). For each 10 Natives the Spaniards appointed one particular Native as the individual in charge. In the present context, parcialidad meant simply a group division.

11. The mountain range referred by Fr. Hidalgo could be the Ouachita Mountains.

12. The Missouri River enters the Mississippi River across from the modern town of Wood River, Illinois.

13. The River de la Palizada is the Mississippi River.

14. The Oliván Rebolledo map (Jackson et al. 1990:Figures 1-4), which was drawn in 1717, portrays rather well the geographic knowledge and the information given by Fr. Hidalgo about the location of the east Texas missions in relation to Queretaro.

15. The Spanish word used in the text is cariaguileño which according to the RAE means: "La persona que tiene el rostro largo y secos los carrillos, al suerte que sobresale algo b naríz " (RAE 1729 :180). Thus, Hidalgo is describing someone whose facial dimensions were longer than wide, and with hollow-like cheeks. These facial characteristics accentuated the prominence of the nose.

16. An olla is a medium to large vessel with a round body and a short narrow neck. Ollas were generally made of clay.

17. According to the RAE, the Nahuatl word atole meant: "Bebida que usan mucho los Mexicanos, que no consiste sino en echar en agua un poco de maíz cocido, exprimir aquella lechilla, colarla y echarla azúcar. Es voz Mexicana usada tambien en Espana" (RAE 1726:471). Thus, atole meant a sweet, thickened broth where corn had been cooked. However, the word atole appears to have been used to designate broths and stews in which one of the ingredients was corn.

18. The Spanish word is estrado which according to the RAE means: "El conjunto de alhayas que sirve para cubrir y adornar el lugar ò pieza en que se sientan las señoras para recibir las visitas, que se compone de alfombra ò tapéte almohadas, taburétes ò sillas baxas" (RAE 1732:644). The plural of estrado, estrados, however is said to mean: "las salas de los conséjos y Tribunales Reales, donde los consejéros y oidores assisten para oir las cáusas, juzgarlas y sentenciarlas" (RAE 1732:644). Thus, estrado meant the set of decorative carpets, rugs, cushions, footstools or low chairs that served as floor coverings and adornment in the drawing-rooms of ladies. The word in its plural form, however, meant the council or court rooms where the councilmen or the Royal judges met to hear and adjudicate court cases. The typescript shows the word in its plural form, but it appears to refer to the ladies' drawing-rooms since it shows an abbreviation (sras) that very likely stands for señoras - ladies. It is likely that Fr. Hidalgo was suggesting the exportation of the Texas rugs to the drawing-rooms of high society ladies in Mexico. 
19. The word that appears in the text is Nozcones which the author could not find in the various dictionaries consulted. It is possible that the word is actually Moscones, large flies, likely horse-flies, which tormented the animals. In 1854, Captain R. B. Marcy while traveling in East Texas reported the presence of "a large, greenish brown horse fly, the most inveterate blood sucker of the genus" (Parker 1984:32). He added that they were innumerable and that he "had seen a horse bathed in his own blood" (Parker 1984:32).

20. It appears that Fr. Hidalgo did not travel to the Trinity River because he specifies that his information came from the Tejas. Later when he refers to the Sapinay lagoon he states that he had personally surveyed the area.

21. Fr. Hidalgo must be referring to La Salle's Fort Saint Louis on Garcitas Creek.

22. The subject of the sentence is not clear, but it appears that it refers to the Native groups in the area constituting an integrated body. Whether Fr. Hidalgo's intent is to indicate a linguistic, associative, or political body is not clear.

23. It appears that Fr. Hidalgo surveyed the area for Spanish settlement from west to east, traveling parallel to the coast line. The contemporary maps (Jackson et al. 1990:Figures 7-9 and 14) do not show any inland lagoon. The Le Maire Map which was published in 1716 (Jackson et al. 1990:Figure 10) shows what could have been perceived as an inland lagoon at the mouth of the Trinity River and another at the mouth of the Colorado or San Marcos River. The Delisle Map of 1718 also shows two prominent coastal bays: one at the mouth of the Rio de San Marcos or Colorado (Matagorda Bay) and another at the mouth of the Rio de la Trinite (Galveston Bay) (Jackson et al. 1990:Figure 14). None of these "lagoons" were located above the junction of any two rivers.

24. Mattie Hatcher's (1927:58) translation does not give the meaning of the word Sapinay and it makes unclear that Sapinay was the name given to the lagoon. The use of a Caddoan word for the lagoon indicates that Fr. Hidalgo was guided by the Tejas. The Caddoan word Sapinay is said to mean pregnant. It is possible that the word referred to the abundance of fish, the particular shape of the lagoon, or the possibility that buffalo cows bred in the area.

25. The river of the Caddodachos is the Red River.

26. The 390 mile distance places the Pawnee villages in the area of the Platte and Loup Rivers.

27. Several Apache groups were located west of the Pawnee and had been experiencing serious problems with the latter as confirmed by the events of the Ulibarri expedition of 1706, the 1719 Valverde expedition, and the 1720 Vilassur disaster. Various Apaches groups occupied areas north of the Canadian River and between the Arkansas and the Kansas rivers. The author is not aware of any compilation of materials about this period that deals in depth with the various Apache groups except for Schroeder's A Study of the Apache Indians (1974). Although there are several problems with the positions taken in this work, primarily because of Schroeder's reliance on secondary sources, at present no other work provides adequate documentation for the period.

28. The mountain range should be the Rocky Mountains. 
29. Fr. Juan de Torquemada, a Franciscan friar, wrote the 12 volume Monarquía Indiana which was first published in Sevilla in 1615. The second edition of the work was published in 1723. Fr. Hidalgo was clearly familiar with the first edition of the work and made a point of letting the Viceroy know he was well acquainted with one of the most influential and informative works about the history of the empire. The material about the Japonese appears in Book V of the Monarquía Indiana (Torquemada 1975:2:423--443).

\section{REFERENCES CITED}

Canedo, L. G.

1968 Primeras Exploraciones y Poblamiento de Texas (1686-1694). Instituto Tecnológico y de Estudios Superiores de Monterrey, México.

Griffith, W. J.

1954 The Hasinai Indians of east Texas as Seen by Europeans, 1687-1772. Middle American Research Institute, Philological and Documentary Studies, vol.II no. 3. Tulane University, New Orleans.

Hatcher, M. A.

1927 Description of the Tejas or Asinai Indians 1691-1722, Fray Francisco Hidalgo to the Viceroy November 4, 1716. Southwestern Historical Quarterly 31:53--62.

Hidalgo, Fr. F.

1716 Letter of Fray Francisco Hidalgo to the Viceroy, November 4, 1716. Material from various sources, Box 2 Q235 pp. 2--13. Texas History Center, University of Texas at Austin.

Jackson, J., R. S. Weddle, and W. De Ville

1990 Mapping Texas And The Gulf Coast, The Contributions of Saint-Denis, Oliván, and Le Maire. Texas A\&M University Press, College Station.

Parker, W. B.

1984 [1856] Through Unexplored Texas in the summer and fall of 1854. Texas State Historical Association, Austin.

Perttula, T. K.

1992 "The Caddo Nation": Archaeological \& Ethnohistoric Perspectives. University of Texas Press, Austin.

Polzer, C. W.

1977 Documentary Relations of the Southwest, Project Manual. Arizona State Museum, Tucson.

Real Academia Española (RAE).

1726 Diccionario de la Lengua Castellana. Tomo Primero. Imprenta de Francisco del Hierro, Madrid.

1729 Diccionario de la Lengua Castellana. Tomo Secundo. Imprenta de Francisco del Hierro, Madrid. 
1732 Diccionario de la Lengua Castellana. Tomo Tercer. Imprenta de los Herederos de Francisco del Hierro, Madrid.

1739 Diccionario de la Lengua Castellana. Tomo Quinto and Sexto. Imprenta de los Herederos de Francisco del Hierro, Madrid.

Schroeder, A. H.

1974 A Study of the Apache Indians. Garland Publishing, New York.

Swanton, J. R.

1942 Source Material On The History And Ethnology Of The Caddo Indians. Bulletin 132. Smithsonian Institution, Bureau of American Ethnology, Washington, D.C.

Torquemada, Fr. J. de

1975 [1615] Monarquía Indiana, vol. II. Universidad Nacional Autónoma de México, México.

Wade, M. F.

1998 The Native Americans of the Texas Edwards Plateau and Related Areas: 15281799. Ph.D. dissertation, Department of Anthropology, The University of Texas at Austin. 